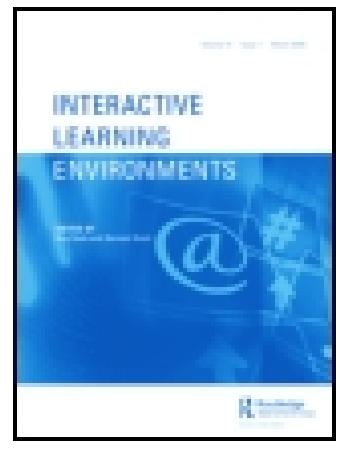

Interactive Learning Environments

\title{
Online learning amidst covid-19 pandemic - explicating the nexus between learners' characteristics, their learning environment and the learning outcomes in built environment studies
}

\author{
Hun-Chuen Gui, Shirly Siew-Ling Wong, Afzan Ahmad Zaini \& Nurakmal
} Abdullah Goh

To cite this article: Hun-Chuen Gui, Shirly Siew-Ling Wong, Afzan Ahmad Zaini \& Nurakmal Abdullah Goh (2021): Online learning amidst covid-19 pandemic - explicating the nexus between learners' characteristics, their learning environment and the learning outcomes in built environment studies, Interactive Learning Environments, DOI: 10.1080/10494820.2021.1978504

To link to this article: https://doi.org/10.1080/10494820.2021.1978504

曲 Published online: 19 Sep 2021.

Submit your article to this journal $₫$

Q View related articles $\sqsubset$

View Crossmark data \lceil 


\title{
Online learning amidst covid-19 pandemic - explicating the nexus between learners' characteristics, their learning environment and the learning outcomes in built environment studies
}

\author{
Hun-Chuen Gui $\mathbb{1}^{\mathrm{a}}{ }^{\text {, Shirly Siew-Ling Wong }}{ }^{\mathrm{b}}$, Afzan Ahmad Zaini ${ }^{\mathrm{a}}$ and \\ Nurakmal Abdullah Goh ${ }^{\mathrm{a}}$ \\ ${ }^{\mathrm{a}}$ Faculty of Built Environment, Universiti Malaysia Sarawak, Malaysia; ${ }^{\mathrm{b}}$ Faculty of Economics and Business, Universiti \\ Malaysia Sarawak, Malaysia
}

\begin{abstract}
The onslaught of Covid-19 has fundamentally upended the landscape of learning in universities. Learners from diverse backgrounds were abruptly forced into the sphere of online learning. Therefore, question arises whether learners from different backgrounds or learners' characteristics, together with their learning environment, would impact the outcomes of online learning. Using Astin's Input-Environment-Outcome (I-E-O) model, this study aims to explicate the nexus between the learners' characteristics, their learning environment and outcomes of online learning. For this purpose, the instrument on Benchmarking Best Practices in Web-Based Courses has been adopted to capture the perception of online learners amidst the pandemic. A survey was administered digitally to students of Built Environment studies, namely the Architecture and Quantity Surveying programmes. Data from 187 respondents were analysed utilising mean analysis, factor analysis, correlation, as well as hierarchical multiple regression. Findings revealed that learners' characteristics did not correlate highly $(r \leq 0.50)$ with either the learning environment or the learning outcomes. However, learning environment was found to correlate strongly $(r \geq 0.50)$ with learning outcomes. Additionally, results from hierarchical multiple regression suggested that characteristics of learners, together with learning environment, positively influenced outcomes of online learning $\left(R^{2}=0.679, p<0.01\right)$. This interesting result offered alternative empirical evidence when compared to past study.
\end{abstract}

\section{ARTICLE HISTORY}

Received 8 April 2021

Accepted 3 September 2021

\section{KEYWORDS}

I-E-O model; online learning; learning outcomes; learning environment; learners' characteristics; covid-19

\section{Introduction}

It is pellucid that the Covid-19 Pandemic has been unsparing in its impact towards the global economy. In the same way, it has also deeply disrupted the way we go about our daily lives, which includes education - from pre-school to primary, secondary, all the way to tertiary education (The Star, 2021; World Economic Forum, 2020a, 2020b). However, this paradigm shift has unanticipatedly presented a myriad of new opportunities, especially for those who embrace the online learning platforms (Murphy, 2020; World Economic Forum, 2020c). In other words, online learning has manifested itself as the silver lining against the dark clouds of the outbreak. 